UDK 542.946.7; 543.272.75

DOI. 10.37878/2708-0080/2020.008

\title{
CATALYTIC TECHNOLOGIES FOR INCREASING QUALITY OF MOTOR FUELS
}

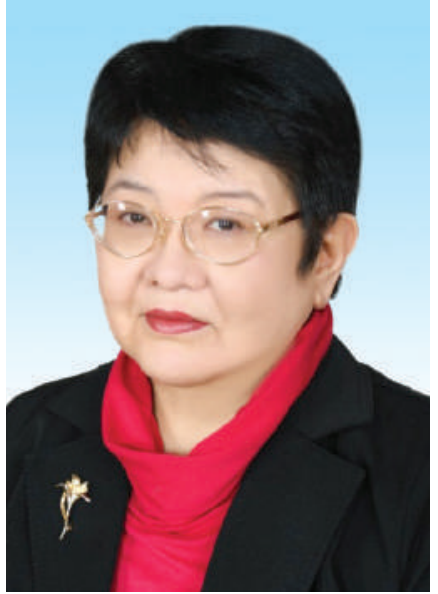

A.T. MASSENOVA ${ }^{1}$,

Doctor of chemical sciences, Head of Lab. of Catalytic synthesis

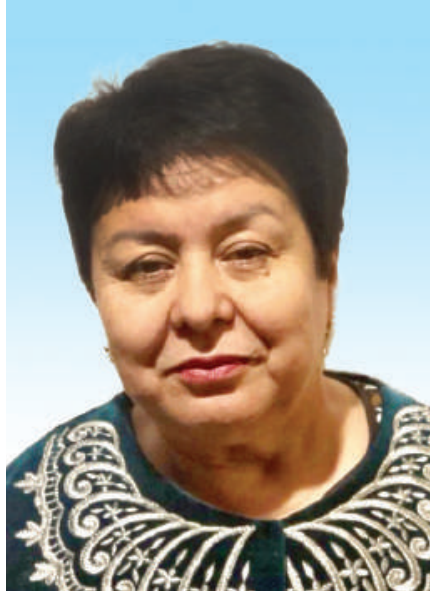

D.Sh. KASSENOVA',

Candidat of chemical sciences, senior research worker

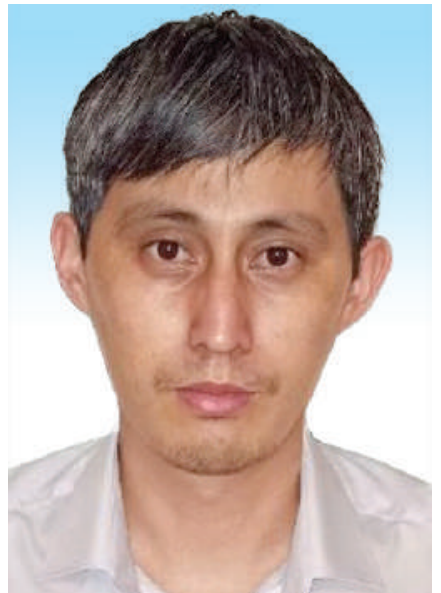

M.K. KALYKBERDIYEV', PhD student, junior research worker

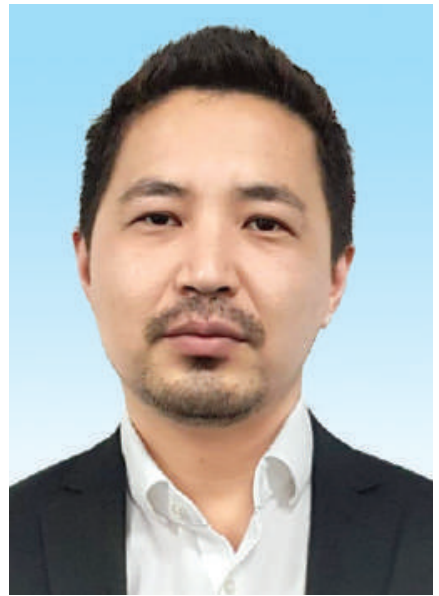

Kh. MAKANOV', undergraduate

1 JSC «Institute of Fuel, Catalysis and Electrochemistry named after D.V. Sokolski», Republic of Kazakhstan, 050010, Almaty, 142 Kunaev str.

${ }^{2}$ Aturau University of Oil and Gas,

Republic of Kazakhstan, 060000, Atyrau, 1 Azattyk str.

*Автор для переписки. E-mail: almasenova@mail.ru 
The aim of the work was to study the process of hydrodearomatization and alkylation of gasoline fractions under increased hydrogen pressure. It has been used Rh-Pt (9:1)/Al $\mathrm{O}_{3}$ catalyst in the work. It has been studied the hydrogenation of three gasoline fractions of "Atyrau Oil Refinery» LLP and Pavlodar Petrochemical Plant LLP. Technological parameters of the process of hydrodearomatization for the production of environmentally friendly fuels, containing no benzene and low in aromatic hydrocarbons have been worked out (pressure, temperature). Data on group composition of organic substances in gasolines demonstrate that after catalytic hydrogenation benzene in final samples of two fractions is absent. For hydrogenizate, the aromatic content decreased from 11.12 weight $\%$ to 2.20 weight $\%$. For stable catalysate, the amount of aromatics decreased from 51.5 weight \% to 10.96 weight \%. Catalytic systems based on zeolites ZSM5 and Y modified with Mg, La, and Ce were tested during the alkylation of 2 gasoline fractions of Atyrau Oil Refinery LLP. It was established that benzene fractions was removed by 30-37\% from gasoline and the content of aromatic hydrocarbons, toluene and cumene decreased by 6-10\%. The catalysts were studied by BET, porometry and EM methods, which established a uniform formation of nanoscale particles on the catalyst surface.

KEY WORDS: catalysts, hydrogenation, hydrodearomatization, alkylation, aromatic hydrocarbons, benzene, gasoline.

\section{КАТАЛИТИЧЕСКИЕ ТЕХНОЛОГИИ ПОВЫШЕНИЯ КАЧЕСТВА МОтОРНЫХ тОПЛИв}

А.Т. МАСЕНОВА ${ }^{1}$, доктор химических наук, зав. лабораторией каталитического синтеза им. Ф.Бижанова

М.К. КАЛЫКБЕРДИЕВ ${ }^{1}$, докторант, младший научныЙ сотрудник

Д.Ш. КАСЕНОВА ${ }^{1}$, кандидат химических наук, старший научный сотрудник

Х.МАКАНОВ ${ }^{2}$, магистрант

${ }^{1}$ АО «Институт топлива, катализа и электрохимии им. Д.В. Сокольского», Республика Казахстан, г. Алматы, Кунаева, 142

${ }^{2}$ Атырауский университет нефти и газа,

Республика Казахстан, г. Атырау, пр. Азаттык, 1

Целью работы являлось изучение процессов гидродеароматизации и алкилирования бензиновых фрракций. В работе использовался Rh-Pt(9:1)/Al $\mathrm{O}_{3}$ катализатор. Изучено гидрирование и алкилирование трех бензиновых фракций ТОО «Атырауский нефтеперерабатывающий завод» и ТОО «Павлодарский нефртехимический завод». Отработаны технологические параметры процесса гидродеароматизации и алкилирования для производства экологически чистых топлив, не содержащих бензол и с низким содержанием ароматических углеводородов (давление, температура). Данные по групповому составу органических веществ в бензинах свидетельствуют о том, что после каталитического гидрирования бензол в конечных пробах двух фрракций отсутствует. Для гидрогенизата содержание ароматических углеводородов снизилось с 11,12 мас.\% до 2,20 мас.\%. Для стабильного катализата количество ароматических углеводородов уменьшилось с 51,5 мас.\% до 10,96 мас.\%. Каталитические системы на основе цеолитов ZSM5 и Y, модифицированных Mg, La u Ce испытаны в процессе алкилирования 2 бензиновых фракций АНПЗ. Установлено, что бензол из бензиновых фрракций был удален на 30-37\%, а содержание ароматических углеводородов, толуола и кумола снизилось на 6-10\%. Катализаторы исследованы методами БЭТ, порометрии и ЭМ, которые установили равномерное образование на поверхности катализаторов наноразмерных частиц. 
КЛЮЧЕВЫЕ СЛОВА: катализаторы, гидрирование, гидродеароматизация, алкилирование, ароматические углеводороды, бензол, бензин.

\title{
МОТОР ОТЫНДАРЫНЫН САПАСЫН АРТТЫРУҒА АРНАЛҒАН КАТАЛИТИКАЛЫҚ ТЕХНОЛОГИЯЛАР
}

\author{
А.Т. МАСЕНОВА ${ }^{1}$, химия ғылымдарының докторы, Ф. Бижанов атындағы каталитикалық \\ синтез зертханасының меңгерушісі. \\ М.К. КАЛЫКБЕРДИЕВ ${ }^{1}$, КБТУ докторанты, кіші ғылыми қызметкер \\ Д.Ш.КАСЕНОВА ${ }^{1}$, химия ғылымдарының кандидаты, аға ғылыми қызметкер \\ X.MАКАНОВ ${ }^{2}$, магистрант \\ ${ }^{1}$ «Д.В. Сокольскийатындағыжанармай, катализ және электрохимия институты» \\ АҚ, Қазақстан Республикасы, Алматы қаласы, Қонаев көшесі 142 \\ ${ }^{2}$ Атырау мұнай және газ университеті, \\ Қазақстан Республикасы, Атырау қаласы, Азаттық даңғылы 1
}

Жұмыстың мақсаты - бензин фрракцияларын сутектендіру және алкилдеу процесінде сутеаінің жоғары қысымында зерттеу. Жұмыс барысында Rh-Pt(9:1)/Al $\mathrm{O}_{3}$ катализаторы қолданылды. ЖШС «Атырау мұнай өңдеу зауытының» және «Павлодар мұнайхимия зауытының» ЖШС бензин фрракцияларын сутектендіру процесі зерттелінді. Құрамында бензол жоқ және төмен мөлшердегі хош иісті көмірсутектері бар экологиялық таза жанармайлар өндіру үшін гидродеароматизация процесінің технологиялық параметрлері жасалынды (қысым, температура). Жанармайдағы органикалық қосылыстардың топтық құрамының көрсеткіштері бойынша каталитикалық сутектендіру процесінен соң бензол компоненті екі бензин фрракцияларының құрамынан толығымен жойылды. Гидрогенизат фрракциясы бойынша хош иісті көмірсутектер мөлшері 11,12 мас.\%-дан 2,20 мас.\%-ға дейін төмендеді. Тұрақты катализат фрракциясы бойынша хош иісті көмірсутектер мөлшері 51,5 мас. \%-дан 10,96 мас. \%-ға дейін төмендеді. Mg, La және Cе-мен модифиикацияланған ZSM5 және Y цеолиттеріне негізделген каталитикалық жүйелер ЖШС «Атырау мұнай өңдеу зауытының» 2 бензин фрракциясын алкилдеу кезінде сыналды. Бензин фрракцияларынан бензол 30-37\% -ға дейін төмендеді, ал хош иісті көмірсутектер, толуол және кумол 6-10\%-ға дейін төмендегені анықталды. Катализаторлар БЭТ әдісі, порометрия және электрондық микроскопта зерттелінді.

НЕГІЗГІ СӨЗДЕР: катализаторлар, сутектендіру, гидродеароматизация, алкилдеу, хош иісті көмірсутектер, бензол, бензин.

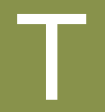

echnical progress in various fields of engineering, operating machinery and the laws on the protection of the biosphere are tightening requirements for the quality of fuels and oils. Continuously deteriorating environmental conditions in the world dictate the need of exploitation of environmentally friendly and high-quality fuel [1]. The quality of fuels largely depends on the hydrocarbon composition. Aromatic hydrocarbons in fuels are represented by monoaromatic compounds: benzene, toluene, xylene isomers and polyaromatic ones - naphthalene, tetraline and other condensed aromatic compounds.

The sources of benzene in automotive gasoline at the modern refinery are the following components: catalytic reforming gasoline $-78.2 \%$; catalytic cracking gasoline residue $-10.2 \%$; light hydrocracking gasoline $-10.9 \%$; coking gasoline $-0.7 \%$. At reforming plants $58 \%$ aromatics are formed and the benzene content can exceed $3 \%$. 
However, these compounds are the most toxic of all hydrocarbon groups; they form toxic substances at combustion. Particularly dangerous is benzene, which forms benzopyrene during combustion, which, according to its degree of toxicity, belongs to the first hazard class with a maximum permissible concentration of $0.000001 \mathrm{mg} / \mathrm{m}^{3}$ and it is a strong carcinogen. When 1 liter of gasoline is burned, benzpyrene is formed up to $81 \mu \mathrm{g}$ in the exhaust gases, and up to $170 \mu \mathrm{g}$ in case of liter of diesel fuel. According to gasoline standards EURO- 6 the content of benzene must be less than $0.1 \%$, and aromatic hydrocarbons is $11 \%$.

Benzene reduction in reforming products is possible by the following methods [2-4]:

- hydrogenation of benzene with the formation of cyclohexane, leading to some decrease in the octane number of the component;

- extraction of pure benzene, cost-effective only with its further effective use;

- alkylation with low molecular weight olefins, which allows not only to solve the problem of benzene removal, but also to increase the yield of the target high-octane component;

- hydroisomerization of benzene to cyclohexane followed by isomerization to methylcyclopentane with a slight increase in the octane number and yield of the target component;

- transalkylation of benzene and aromatic hydrocarbons $\mathrm{C} 9+$, leading to a decrease in the yield of the target product;

- fractionation of the reformate to obtain a set of fractions, then mixed in various proportions to achieve the desired result,

- reforming + hydroisomerization of benzene - hydrogenation of benzene to cyclohexane followed by isomerization to methylcyclopentane (RIGIZ).

The authors of RIGIZ [1] explain the benefits of hydroisomerization of cyclohexane to methylcyclopentane with a higher octane number of the latter 92 , while cyclohexane has 88 units.

The most effective methods for improving the operational properties of fuels, in our opinion, are their hydrodearomatization and alkylation in the presence of effective catalysts. Catalytic hydrogenation and alkylation of aromatic hydrocarbons allows to change the chemical structure of hydrocarbons in the right direction and to improve the operational characteristics of motor fuels [5-9].

In industry, for the hydrogenation processes, both catalysts based on metals of group VIII and sulfide are used, but in the latter, the hydrogenation of benzene and aromatic hydrocarbons is carried out under more severe conditions. For industrial alkylation processes, catalysts based on different zeolites are used.

The aim of this work is to study the catalytic hydrodearomatization and alkylation of three gasoline fractions of Atyrau Oil Refinery LLP and Pavlodar Petrochemical Plant LLP in order to reduce the content of benzene and aromatic hydrocarbons on supported catalysts based on group VIII metals and alkylation on zeolite-containing catalysts.

The tests of the catalysts in the process of hydrodearomatization and alkylation were carried out on an autoclave of Amar Equipment Ltd and Finetech 4000, intended for hydrogenation processes with heating and under hydrogen pressure above atmospheric. Analysis of the reaction products was carried out on a Crystallux-4000M chromatograph: Zebron ZB-1 column filled with dimethylsiloxane, column length $30 \mathrm{~mm}$, column diameter 


\section{НЕФТЕХИМИЯ}

$0.53 \mathrm{~mm}$. The hydrodearomatization products of gasoline fractions were also studied by IR spectroscopy.

The process of hydrodearomatization of two gasoline fractions was studied: Stable catalysate AOR (Atyrau Oil Refinery LLP)and Stable catalysate PPP (Pavlodar Petrochemical Plant LLP) on the prepared Rh-Pt/Al $\mathrm{O}_{3}$ catalysts. The content of benzene and aromatic hydrocarbons in different gasoline fractions is given in table 1 . The aromatics content is high, because these fractions after reforming.

\section{Table 1 - Content of benzene and aromatic hydrocarbons in the gasoline fractions of AR LLP and POCR LLP}

\begin{tabular}{|c|c|c|}
\hline Name of fraction & Content of benzene, mass $\%$ & Content of aromatics, mass $\%$ \\
\hline Stable catalysate AOR & 3.23 & 55.04 \\
\hline Stable catalysate PPP & 1.0 & 58.68 \\
\hline
\end{tabular}

The catalyst used was $\mathrm{Rh}-\mathrm{Pt}(9: 1) / \mathrm{Al}_{2} \mathrm{O}_{3}$, which was most effective in the hydrogenation of individual benzene and toluene [10]. The effect of temperature and pressure of hydrogen on the process of hydrogenation of benzene and aromatic hydrocarbons for two gasoline fractions was studied.

The effect of the content of the active catalytic phase on the composition of the components of 2 gasoline fractions was studied during hydrodearomatization on $0.2 \%$ $\mathrm{Rh}-\mathrm{Pt} / \mathrm{Al}_{2} \mathrm{O}_{3}, 0.5 \% \mathrm{Rh}-\mathrm{Pt} / \mathrm{Al}_{2} \mathrm{O}_{3}$ and $1.0 \% \mathrm{Pt}-\mathrm{Rh} / \mathrm{Al}_{2} \mathrm{O}_{3}$ catalysts at $50^{\circ} \mathrm{C}$ and $0.4 \mathrm{MPa}$ (Fig. 1). With an increase in the content of the active phase, the conversion of aromatic hydrocarbons increases, their content decreases from 55.04 to $34.7 \%$ for the catalyst $0.2 \%$ $\mathrm{Rh}-\mathrm{Pt} / \mathrm{Al}_{2} \mathrm{O}_{3}$, up to $28.60 \%$ for the catalyst $0.5 \% \mathrm{Rh}-\mathrm{Pt} / \mathrm{Al}_{2} \mathrm{O}_{3}$ and up to $26.11 \%$ for the
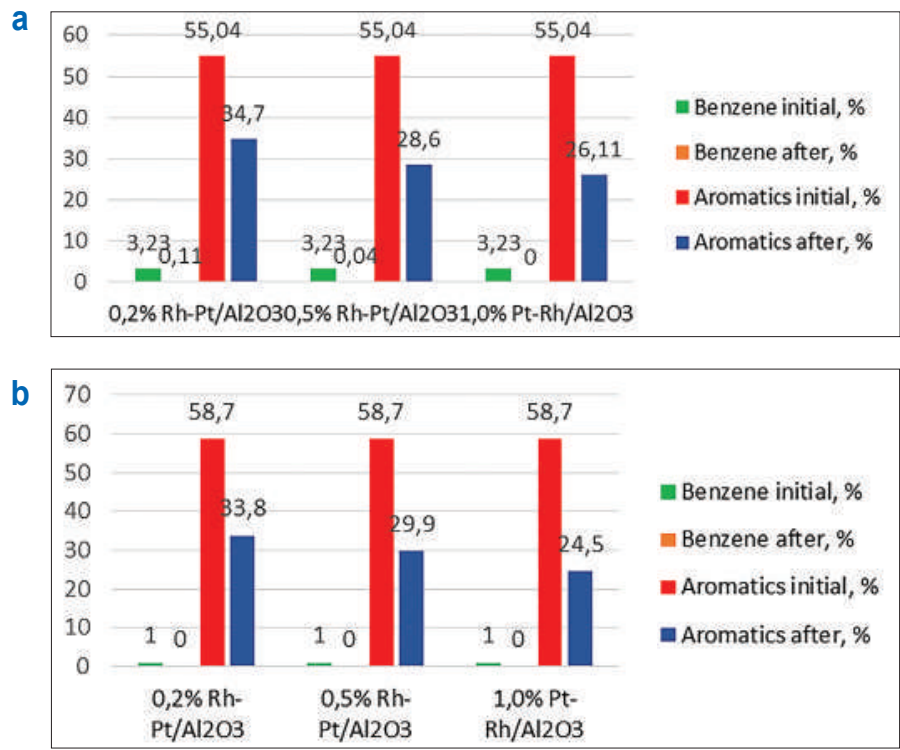

a - Stable catalysate of AOR, b - Stable catalysate of PPP

Figure 1 - Hydrogenation of gasoline fractions on catalysts $0.2 \%, 0.5 \%$ and $1.0 \% \mathrm{Rh} / \mathrm{Al}_{2} \mathrm{O}_{3}$ at $50^{\circ} \mathrm{C}$ and $0.4 \mathrm{MPa}$ 


\section{НЕФТЕХИМИЯ}

catalyst $1.0 \% \mathrm{Pt}-\mathrm{Rh} / \mathrm{Al}_{2} \mathrm{O}_{3}$. On all three catalysts, benzene is completely removed from the two fractions.

It has been studied the influence of technological parameters of the process of hydrodearomatization of gasoline fractions (pressure $1-5 \mathrm{MPa}$, temperature $50-200^{\circ} \mathrm{C}$ ) on the content of benzene and aromatic hydrocarbons. At temperatures of $50-200^{\circ} \mathrm{C}$ and hydrogen pressures of 2-5 MPa, benzene is completely removed from 3 fractions, and the amount of aromatic hydrocarbons is reduced to 1.5-2 times (table 2). During gasoline hydrogenation of Stable catalysate AOR, the content of aromatic hydrocarbons at $50-200^{\circ} \mathrm{C}$ decreased from $55.04 \%$ to $20.21 \%$, and with increasing pressure from 1.0 to $5.0 \mathrm{MPa}$ it decreased from 55.04 to $22.91 \%$. At gasoline hydrogenation of Stable catalysate PPP in the temperature range of $25-200^{\circ} \mathrm{C}$ the aromatics content reduced from $58.68 \%$ to $24.89 \%$, and when the pressure changed from 1.0 to $5.0 \mathrm{MPa}$, it decreased from $58.68 \%$ to $26.55 \%$.

\section{Table 2 - Hydrodearomatization of fractions of Stable catalysate AOR and Stable catalysate PPP on $0.5 \% \mathrm{Pt}-\mathrm{Rh} / \mathrm{\gamma}-\mathrm{Al}_{2} \mathrm{O}_{3}$}

\begin{tabular}{|c|c|c|c|c|c|}
\hline \multirow{2}{*}{\multicolumn{2}{|c|}{ Conditions }} & \multicolumn{2}{|c|}{ Benzene, \% mas. } & \multicolumn{2}{|c|}{ Aromatics, $\%$ mas. } \\
\hline & & Initial, \% & After experiment, $\%$ & Initial, \% & After experiment, \% \\
\hline \multicolumn{6}{|c|}{ Stable catalysate AOR } \\
\hline \multirow{5}{*}{$\begin{array}{c}\mathrm{P} \\
\mathrm{MPa} \\
\text { at } 50^{\circ} \mathrm{C}\end{array}$} & 1,0 & \multirow{5}{*}{3,23} & 0,11 & \multirow{5}{*}{55,04} & 41,11 \\
\hline & 2,0 & & 0,04 & & 37,62 \\
\hline & 3,0 & & 0,01 & & 34,55 \\
\hline & 4,0 & & - & & 28,56 \\
\hline & 5,0 & & - & & 22,91 \\
\hline \multirow{5}{*}{$\begin{array}{c}\mathrm{T},{ }^{\circ} \mathrm{C} \\
\text { at } 4 \mathrm{MPa}\end{array}$} & 25 & \multirow{5}{*}{3,23} & - & \multirow{5}{*}{55,04} & 35,69 \\
\hline & 50 & & - & & 28,56 \\
\hline & 100 & & - & & 25,87 \\
\hline & 150 & & - & & 23,54 \\
\hline & 200 & & - & & 20,21 \\
\hline \multicolumn{6}{|c|}{ Stable catalysate PPP } \\
\hline \multirow{5}{*}{$\begin{array}{c}\mathrm{P}, \\
\mathrm{MPa} \\
\text { at } 50^{\circ} \mathrm{C}\end{array}$} & 1,0 & \multirow{5}{*}{1,0} & 0,62 & \multirow{5}{*}{58,68} & 50,77 \\
\hline & 2,0 & & 0,05 & & 47,21 \\
\hline & 3,0 & & 0,01 & & 32,95 \\
\hline & 4,0 & & - & & 29,98 \\
\hline & 5,0 & & - & & 26,55 \\
\hline \multirow{5}{*}{$\begin{array}{c}\mathrm{T},{ }^{\circ} \mathrm{C} \\
\text { at } 4 \mathrm{MPa}\end{array}$} & 25 & \multirow{5}{*}{1,0} & - & \multirow{5}{*}{58,68} & 35,83 \\
\hline & 50 & & - & & 29,98 \\
\hline & 100 & & - & & 28,34 \\
\hline & 150 & & - & & 25,98 \\
\hline & 200 & & - & & 24,89 \\
\hline
\end{tabular}

In addition to chromatographic analysis, we analyzed the change in the composition of the catalysate before and after hydrodearomatization by IR spectroscopy. Table 3 shows the absorption bands in the IR spectrum of two gasoline fractions. Absorption bands related to the $\mathrm{C}=\mathrm{C}$ bonds of the benzene ring $\left(3014-3017 \mathrm{~cm}^{-1}\right.$ and $\left.1378,1342 \mathrm{~cm}^{-1}\right)$ are absent after the reaction, which once again proves the complete removal of benzene and a significant reduction in aromatics. 
Table 3 - IR spectra of gasoline fractions PPP and AOR $\left(\mathrm{cm}^{-1}\right)$

\begin{tabular}{|c|c|c|c|c|}
\hline \multicolumn{2}{|c|}{ Gasoline PPP } & \multicolumn{2}{|c|}{ Gasoline AOR } & Attributions \\
\hline initial & after experiment & initial & after experiment & \\
\hline & & & 3088 & \\
\hline & 3020 & & 3030 & Valent fluctuations \\
\hline 3017 & & 3014 & & benzene ring $=\mathrm{CH}-$ \\
\hline 0,5 & 0,5 & 0,2 & & \\
\hline 1609 & 1613 & 1606 & 1606 & \\
\hline 0,15 & 0,3 & 0,3 & 0,1 & Valent fluctuations of \\
\hline 1506 & 15051455 & 15161497 & 15061458 & bond $-\mathrm{C}=\mathrm{C}-$ benzene \\
\hline 1455 & 13781304 & 1465 & 13781345 & ring. \\
\hline 13781342 & - & 13781342 & - & \\
\hline
\end{tabular}

In figure 2 there are shown data on the group composition of organic substances in two gasolines of the initial fractions and after hydrogenation on $\mathrm{Rh}-\mathrm{Pt}(90: 10) / \mathrm{Al}_{2} \mathrm{O}_{3}$ at $3 \mathrm{MPa}$ and $50^{\circ} \mathrm{C}$. For the Stable catalysate AOR, the benzene content in the initial state was 3.23 wt. $\%$, after the reaction, benzene is absent, i.e. $100 \%$ benzene conversion. The amount of aromatics decreased from $55.04 \mathrm{wt} . \%$ to $22.19 \mathrm{wt} . \%$. It should be noted that the number of olefins decreased almost 2 times from $0.23 \%$ to $0.11 \mathrm{wt} . \%$, which is very favorable for gasolines, since the presence of olefins leads to instability (in the chemical expression, the oligomerization and polymerization reaction proceeds). The amount of paraffins slightly increased from $12.22 \mathrm{wt} . \%$ to $12.99 \mathrm{wt} . \%$. And the content of isoparaffins increased from $27.16 \mathrm{wt} . \%$ to $36.81 \mathrm{wt} \%$. Apparently, the isomerization of paraffins to isoparaffins occurred. The content of naphthenes increased sharply from $2.12 \mathrm{wt} . \%$ to
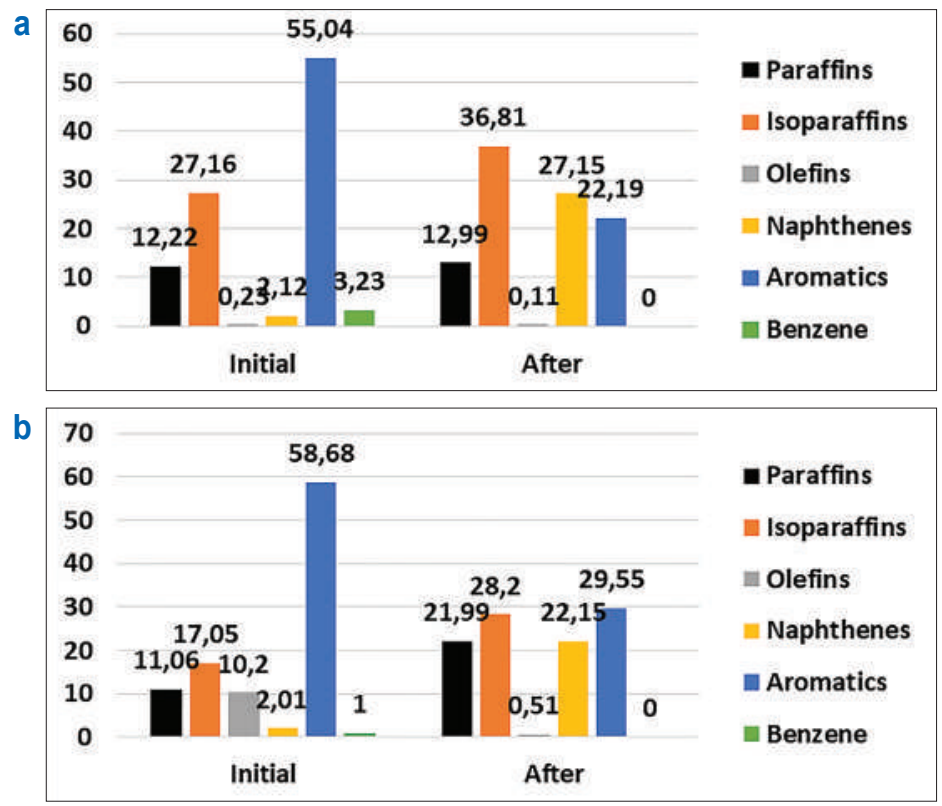

a - Stable catalysate of AOR, b - Stable catalysate of PPP

Figure 2 - Group composition of gasoline fractions on $\mathrm{Pt}-\mathrm{Rh} / \mathrm{Al}_{2} \mathrm{O}_{3}$ 
27.15 wt.\%. The picture is similar for the Stable catalysate PPP: benzene is absent, aromatics decreased from 58.68 to $29.55 \%$, olefins from 10.2 to $0.51 \%$, isoparaffins increased from 17.05 to $28.2 \%$. It should be noted that an increase in the content of paraffins of the isostructure indicates not only the hydrogenation reaction, but also hydroisomerization.

Data on the octane number and the density of the initial gasoline fractions before and after the catalytic treatment are given in table 4 (LLP "Independent Center for the Examination of Petroleum Products ORGANIC"). According to the research method, the octane number after treatment of the Stable catalysate AOR has not changed and is equal to 94 units. And the octane number according to the motor method increased from 82.6 to 82.7 , i.e. in this case also, the octane number has not changed. For Stable catalysate of PPP, the octane number decreased from 90 to 89.9. This indicates that the processing of gasolines practically does not affect the octane number. The density slightly increased after treatment, which is understandable from the point of view of changing the hydrocarbon composition to a heavier region - naphthenes have a higher density compared to aromatic hydrocarbons.

Table 4 - Characteristics of gasoline fractions of Stable catalysate of AOR and Stable catalysate of PPP before and after catalytic treatment

\begin{tabular}{|c|c|c|c|}
\hline Gasoline & Octane number RM & Octane number MM & Density, $\mathrm{g} / \mathrm{cm} 3$ \\
\hline \multicolumn{4}{|c|}{ Stable catalysate AOR } \\
\hline Initial & 94,0 & 82,6 & 0,771 \\
\hline After experiment & 94,0 & 82,7 & 0,780 \\
\hline \multicolumn{4}{|c|}{ Stable catalysate PPP } \\
\hline Initial & 90,0 & Not measured & 0,793 \\
\hline After experiment & 89,9 & Not measured & 0,798 \\
\hline
\end{tabular}

In transmission electron microscopy image (Fig. 3), the $\mathrm{Rh}-\mathrm{Pt}(9: 1) / \mathrm{Al}_{2} \mathrm{O}_{3}$ catalyst is represented by fine particles with a size of $2-2.5 \mathrm{~nm}$ and a small number of denser and larger particles of $5 \mathrm{~nm}$, the microdiffraction patterns of which are represented by diffuse rings corresponding to metals. Metal particles are distributed on the surface of alumina and are mixed bimetallic agglomerates Rh-Pt together with Rh particles. The high activity of the catalyst is possibly due to the formation of alloys of these metals.

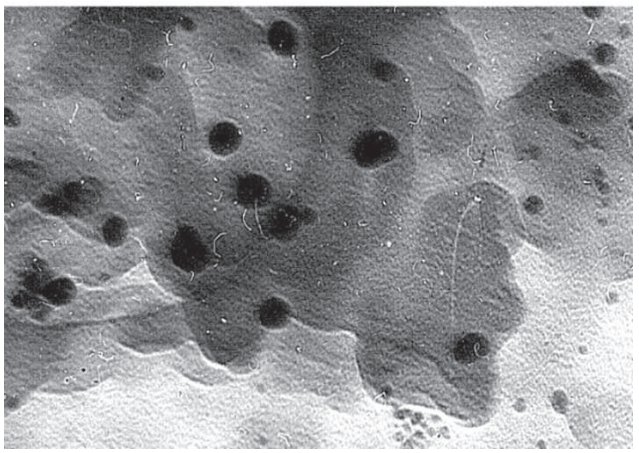

Figure 3 - EM image of 2\% Rh-Pt (9: 1) / Al2O3 (magnification 160,000) 
Alkylation is one of the most important petrochemical processes of hydrocarbon processing, allowing to produce high-octane components of gasoline, intermediate products for synthesis of many important chemical products, in particular monomers for production of polymers and plastics. In Western countries, the specific weight of the alkylation process in the entire oil refining industry is $16-20 \%$, in Russia $-0.1 \%$, in Kazakhstan there is no such process at all, even scientific research in this area has not been carried out.It has been selected the catalytic systems based on zeolites ZSM5 and Y modified with Mg, La, and Ce for alkylation of benzene [11]. The catalysts were tested in the alkylation process of 2 gas oline fractions of refinery. It was found that benzene from gasoline fractions was removed to $30-37 \%$, and the content of aromatic, toluene and cumene decreased to $6-10 \%$.

On the most active catalysts modified with magnesium and lanthanum, alkylation of two gasoline fractions of Atyrau Oil Refinery LLP was carried out - Hydrogenated gasoline and Stable catalysate. The data on the content of benzene, toluene, and cumene in the gasolines of the initial fractions and after alkylation with 5\% Mg-HY (80) are shown in the table 5.

Table 5 - Composition of the gasoline fraction of the initial and after treatment with $5 \%$ $\mathrm{Mg}-\mathrm{HY}(80)$ catalyst at $200^{\circ} \mathrm{C}$

\begin{tabular}{|l|c|c|c|c|}
\hline \multirow{2}{*}{ Name of sample } & \multicolumn{4}{c|}{ Content of defined indicator, mass.\% } \\
\cline { 2 - 5 } & Aromatics & Benzene & Toluene & Cumene \\
\hline Hydrogenated gasoline (initial) & 13,70 & 2,22 & 5,66 & 3,44 \\
\hline After treatment & 12,26 & 1,41 & 0,12 & 0,2 \\
\hline Stable catalysate (initial) & 51,50 & 4,53 & 9,89 & 5,67 \\
\hline After treatment & 48,96 & 3,15 & 0,78 & 0,48 \\
\hline
\end{tabular}

In the initial hydrogenated gasoline there was $2.22 \%$ benzene, after catalytic treatment $1.41 \%$ benzene was found in the catalyzate - i.e. its conversion was $37.5 \%$. The aromatic content of the initial gasoline was $13.70 \%$ and then became $12.26 \%$. The amount of aromatics decreased to $10.6 \%$. In the stable catalysate there was $4.53 \%$ benzene, and it became $3.15 \%$, the conversion of benzene was $30.5 \%$. The amount of aromatics was $51.5 \%$, and after processing $48.59 \%$ - it decreased to $5.6 \%$.

Thus, studies have been carried out on the alkylation of benzene as a model compound and contained in the gasoline fractions of Atyrau Oil Refinery LLP on zeolites HZSM-5, $\mathrm{HY}$ and $\beta$ modified with magnesium and lanthanum. It is shown that as a result of the reaction, benzene was removed from gasolines to $30-37 \%$, and the content of aromatics, toluene and cumene decreased to $6-10 \%$.

Comparing two methods of reducing the content of aromatic hydrocarbons in fuels, we can conclude that hydrogenation is much more efficient:

- removes benzene up to $100 \%$, while during alkylation, the benzene content decreases only to $30-37 \%$; 
- reduces the aromatic content to $41-48 \%$, and alkylation reduces only up to $6-10 \%$;

- conducts the process at low temperatures, i.e. this technology is energy saving.

The advantage of this work is the fact that, in addition to the hydrogenation of benzene and olefins, the process of hydroisomerization of normal alkanes and isostructural alkanes with increased octane numbers proceeds on the catalyst. Catalysts have a dual function: redox catalysis (hydrogenation) and acid-base catalysis (isomerization), which proceeds on a part of the surface represented by a zeolite with pronounced acid centers and alumina.

\section{CONCLUSIONS}

1. On highly effective catalysts $\mathrm{Pt}-\mathrm{Rh} / \gamma-\mathrm{Al}_{2} \mathrm{O}_{3}$ for the hydrogenation of gasolines, allowing to remove completely benzene and as well as reduce the content of aromatic compounds till 2-4 times. The catalyst was tested in the hydrogenation of 2 gasoline fractions - Stable catalysate Atyrau Oil Refinery LLP and Stable catalysate Pavlodar Petrochemical Plant LLP. By the method of studying the influence of temperature and pressure of hydrogen for two gasoline fractions, optimal parameters (temperature $50^{\circ} \mathrm{C}$ and pressure $3 \mathrm{MPa}$ ) were selected for the production of environmentally friendly fuels that do not contain benzene and with a low content of aromatic hydrocarbons.

2. During the hydrodearomatization of gasoline fractions, the Stable catalysate of Atyrau Oil Refinery LLP and the Stable Catalysis of Pavlodar Petrochemical Plant LLP, it is found that bimetallic Pt-Rh catalysts on $\gamma-\mathrm{Al}_{2} \mathrm{O}_{3}$ showed the best activity. The conversion of benzene is $100 \%$, i.e. benzene is completely removed from gasoline fractions.

3 . The group composition after catalytic treatment showed that the content of aromatic hydrocarbons is reduced almost 2 times. In addition, the content of paraffins decreases, and iso-paraffins increases, which indicates that the synthesized catalysts, in addition to hydrogenation, carry out the process of hydroisomerization of normal paraffins into branched iso-paraffins. The octane number of gasoline fractions has not changed significantly.

4. On zeolite catalysts modified with magnesium and lanthanum, alkylation of two gasoline fractions of Atyrau Oil Refinery LLP - hydrogenated gasoline and Stable catalysate were carried out. It is shown that as a result of the reaction, benzene was removed from gasolines to $30-37 \%$, and the content of aromatics, toluene and cumene decreased to $6-10 \%$.

\section{REFERENCES}

[1] Юркина О.В., Краев Ю.Л., де Векки А.В. Гидродеароматизация керосиновых фракций. Нефртепереработка и нефттехимия. 2003;1:24-26. [Yurkina O.V., Krayev Yu.L., deVekki A.V. Hydroaromatization of kerosene fractions. Oil refining and petrochemistry. 2003;1:24-26. (In Russ.)]

[2] Кондрашев Д.О., Ахметов А.Ф. Совместное применение технологии межступенчатой ректификации риформата и процесса РЕГИЗ для получения компонентов бензинов с улучшенными экологическими свойствами. Нефртегазовое дело.2006;3:1-9. [Kondrashev D.O., Akhmetov A.F. Petroleum engineering. 2006;3:1-9. (In Russ.)]

[3] Абдульминев К.Г., Федоринов И.А., Ахметов А.Ф. Исследование технологии получения низкоароматизированных высокооктановых компонентов автомобильных топлив. Башкирский химический журнал. [Abdul'minev K.G., Fedorinov I.A., Akhmetov 


\section{НЕФТЕХИМИЯ}

A.F. Study of the technology for producing low-aromatized high-octane components of automotive fuels. Bashkir Chemical Journal. 2003;10:60-62. (In Russ.)]

[4] Абдульминев К.Г., Манушков В.А., Гибадуллин А.Х. Технологии снижения бензола в бензинах каталитического риформинга. Нефтегазовое дело. 2013;11:137-140. [Abdul'minev K.G., Manushkov V.A., Gibadullin A.Kh. Technologies for reducing benzene in catalytic reforming gasolines. Petroleum engineering. 2013;11:137-140. (In Russ.)]

[5] AbuBakar N.H.H., Bettahar M.M., AbuBakar M., Monteverdi S., Ismail J., Alnot M. Pt-Ni catalysts prepared via borohydride reduction for hydrogenation of benzene. J. Catal. 2009;265:63-71.

[6] Brandão D.S., Galvão R.M., da Graça M., da Rocha M.C., Bargiela P., Sales E.A. Ptan $\underline{\mathrm{dPd} d c a t a l y s t s s u p p o r t e d o n \mathrm{Al}_{2}} \underline{\mathrm{O}}_{3}$ modifiedwithrareearthoxidesinthehydrogenationoftetralin, inthepresenceofthiophene. Catal. Today. 2008;133-135:324-330.

[7] Arun V., Sridevi N., Robinson P.P., Manju S., Yusuff K.K.M. Ni(II) and Ru(II) Schiff base complexes as catalysts for the reduction of benzene. Journal Molec. Catal.A: Chemical. 2009;304:191-198.

[8] Zhou J, Liu Z, et al. Shape selective catalysis in methylation of toluene: Development, challenges and perspectives. Front. Chem. Sci.Eng. 2018;12:103-112.

[9] GuanX., Li N., Wu G., Chen J., Zhang F., Guan N. Para-selectivity of modified HZSM-5 zeolites bynitridation for ethylation of ethylbenzene with ethanol. J.Mol.Catal. A Chem, 2006;248:220-225.

[10] Frolova O.A., Massenova A.T., Sassykova L.R., BashevaZh.T., Baytazin E., Ussenov A. Hydrodearomatization of gasoline fractions of Atyrau oil refinery of the Republic of Kazakhstan. Int. J. Chem. Sci. 2014;12:625-634.

[11] Massenova A.T., Zhaxibayeva A.M., Zhumakanova A.S., Yeligbayeva G.Z., Rafikova K. Benzene alkylation by ethanol over catalysts on the base of modified natural zeolites. Eurasian Chem.Tech.J. 2012;14:211-217. 